\title{
EXPECTED SNOW LOADS ON STRUGTURES FROM INCOMPLETE HYDROLOGICAL DATA
}

\author{
By J. Martinec \\ (Eidgenössisches Institut für Schnee- und Lawinenforschung, 7260 Weissfluhjoch/Davos, \\ Switzerland)
}

\begin{abstract}
An assessment of snow loads in Switzerland was required for a revision of the building code. Settling curves of snow are used to compute water equivalents of snow if direct measurements are not available. Based on a frequency analysis, relations between the snow load and the altitude are given for various return periods. Problems of regional effects and of converting the snow-cover data to roof loads are outlined.

RÉsumé. Estimation des surcharges dues à la neige sur les constructions à partir de données hydrologiques incomplètes. Une étude de la pression de la neige en Suisse a été exigée en connexion avec une revision des normes du bâtiment. Les courbes de tassement de la neige sont utilisées pour calculer l'équivalent en eau en absence des mesures directes. Basées sur l'analyse fréquentielle, les relations entre la pression de la neige et l'altitude sont présentées pour les périodes de retour différentes. Les effets régionaux et la conversion des données sur la couche de neige en pression sur les toits sont traités.

Zusammenfassung. Erwartungswerte für Schneedachlasten aus unvollständigen hydrologischen Daten. Eine Auswertung der Schneelasten in der Schweiz wurde für eine Revision der Bauvorschriften verlangt. Setzungskurven der Schneedecke werden herangezogen, um den Schneewasserwert zu berechnen, falls direkte Messungen fehlen. Aufgrund einer Frequenzanalyse wurden Relationen zwischen der Schneelast und der Meereshöhe für verschiedene Wiederkehrperioden abgeleitet. Probleme der Regionalität und der Umwandlung von Schneedaten in Dachlasten werden behandelt.
\end{abstract}

\section{INTRODUCTION}

A snow load is given by the water equivalent of a snow-pack. Data from snow gauging networks are frequently insufficient for establishing the snow accumulation characteristics for different regions and altitudes. In particular in most countries the direct measurements of the water equivalent of snow are incomplete although their expediency and reliability is gradually improved by new instruments. On the other hand, daily observations of the total depth of snow cover are generally available and can be used for an indirect reconstruction of data.

\section{SETTLing GuRVES OF SNOW}

When the maximum load of a winter is reached, snow has a varying density depending on the preceding build-up of the snow-pack. At Weissfluhjoch, $2540 \mathrm{~m}$ a.s.l., a density of $490 \mathrm{~kg} \mathrm{~m}^{-3}$ was measured at this point in the winter 1975 while in 1949 it was only $290 \mathrm{~kg} \mathrm{~m}^{-3}$ and in lower stations it can be less than $200 \mathrm{~kg} \mathrm{~m}^{-3}$. These examples illustrate the errors to be expected if one converts the snow depth at the point of maximum accumulation into the water equivalent using a constant ratio.

The densification process is reflected in a gradual decrease of snow depth. A settling curve derived following Haefeli (Bader and others, i 939, p. 8o-8i )

$$
H_{\mathrm{s} t}=H_{\text {so }}\left[\left(\mathrm{I}-\frac{\rho_{\mathrm{s}}}{\rho_{\mathrm{i}}}\right) \exp \left(-\beta t^{\alpha}\right)+\frac{\rho_{\mathrm{s}}}{\rho_{\mathrm{i}}}\right],
$$

where $H_{\mathrm{so}}$ is the initial snow depth, $H_{\mathrm{s} t}$ is the snow depth after the elapse of time $t, \rho_{\mathrm{s}}$ is the initial density of snow, $\rho_{\mathrm{i}}$ is the density of ice, $\alpha, \beta$ are parameters related to the temperature, vertical load and type of snow, leads logically to the final depth $H_{\mathrm{s} 0}\left(\rho_{\mathrm{s}} / \rho_{\mathrm{i}}\right)$ corresponding to ice. The settling curve can assume varying shapes which can be simulated by laboratory experiments and described by a more physical approach (de Quervain, r945, 1946).

When there is an immediate practical need of estimating the settling of a natural snow cover, it is not possible to take into account the variation of temperature, wind velocity, load 
of superimposed snow layers and partly the intermittent melting or rain, especially if the pertinent data are not available. In order to meet the demands, a simplified settling equation with a time function can be derived from measurements of snow layers in conditions of a natural snow cover, such as

$$
H_{\mathrm{s} n}=H_{\mathrm{so}}(n+\mathrm{I})^{-0.3},
$$

where $H_{\mathrm{so}}$ is the depth of new snow measured on the first morning after snowfall and $H_{\mathrm{s} n}$ is the depth of snow after $n$ days.

The validity of such an equation is limited to snow conditions and to the time period in which it was derived. The theoretical merit of converging to a depth corresponding to ice after a very long time is not fulfilled (such extrapolation is anyhow questionable due to the increasing effect of evaporation and is of no practical interest for a seasonal snow cover). The aim is to obtain a good estimate of snow density attained at the point of the maximum snow accumulation (in terms of the water equivalent) of a winter.

Equation (2) was originally derived in the Krkonoše mountains in Central Europe (Martinec, I956). In Figure $\mathrm{I}$ it is compared with an example of a settling curve obtained with regulated temperature conditions in a laboratory.

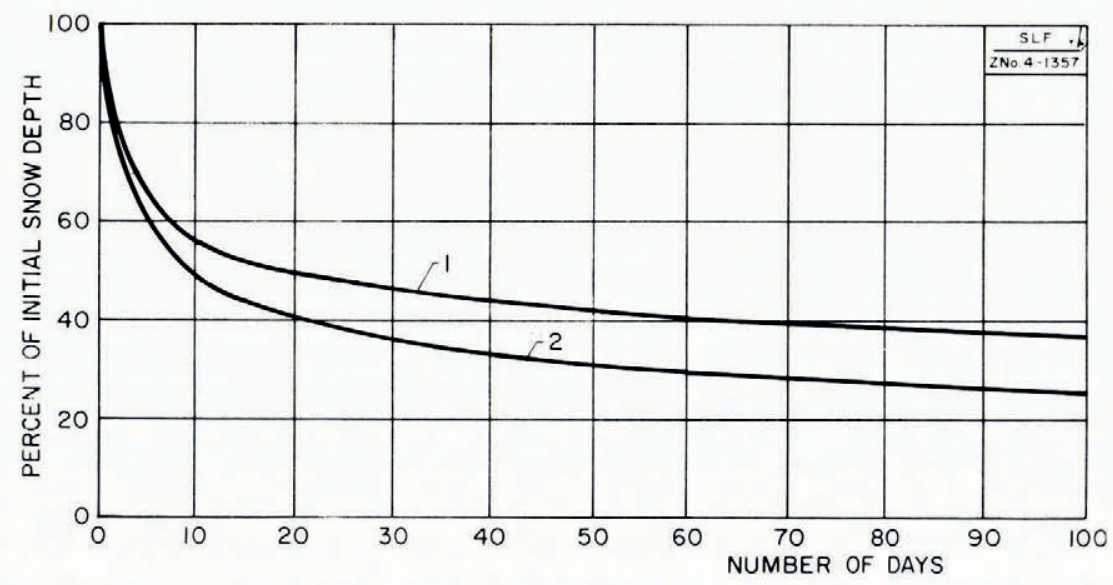

Fig. I. Comparison of settling curves, I. de Quervain (1945), $T=-2.5^{\circ} \mathrm{C}, \rho_{0}=11_{5} \mathrm{~kg} \mathrm{~m}^{-3}$, 2. Martinec (1956), natural snow cover 14 IO $m$ a.s.l.

\section{Simulation OF THE WATER EQUIVALENT OF SNOW}

The mean density of snow is related to its water equivalent $H_{\mathrm{w}}$ and depth $H_{\mathrm{s}}$ by the equation

$$
H_{\mathrm{s}}=\frac{H_{\mathrm{w}} \rho_{\mathrm{w}}}{\rho}
$$

where $\rho_{\mathrm{w}}$ is the density of water and, substituting in Equation (2),

$$
\frac{H_{\mathrm{w} n}}{\rho_{n}}=\frac{H_{\mathrm{w} 0}}{\rho_{0}}(n+\mathrm{I})^{-0.3} \text {. }
$$

Neglecting the evaporation, $H_{\mathrm{w} n}$ equals $H_{\mathrm{wo}}$ and Equation (3) becomes

$$
\rho_{n}=\rho_{0}(n+\mathrm{I})^{0.3} \text {. }
$$

In order to calculate $\rho_{n}$ and $H_{\mathrm{w} n}$ a reasonable value of $\rho_{0}$ is thus needed. 
When an assessment of snow loads in Switzerland was requested for a revision of building standard specifications, Equation (2) was found also to approximate the average conditions in the Alps if $\rho_{0}=100 \mathrm{~kg} \mathrm{~m}^{-3}$ was substituted equally as in previous applications. By a computerized procedure, the sequence of daily total depths was converted into daily water equivalents so that the maximum could be determined for each year. Figure 2 shows this simulation compared with direct measurements carried out twice a month in two Alpine stations.

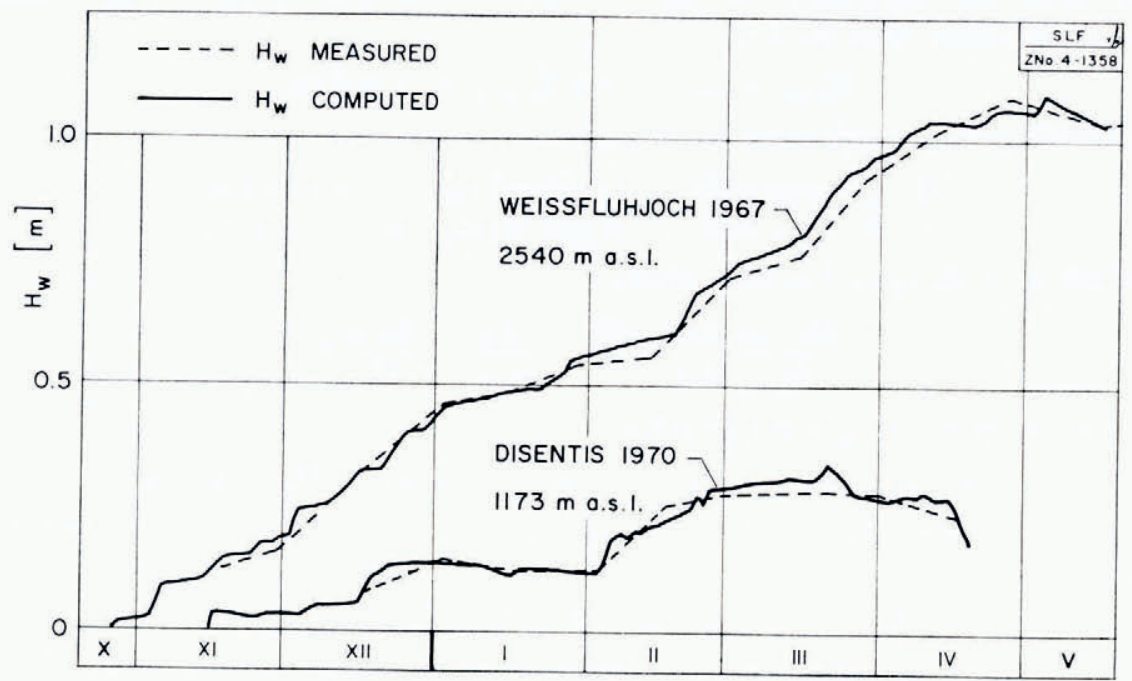

Fig. 2. Snow water-equivalents computed from snow depths compared with direct measurements.

An approximation which is satisfactory in different localities seems surprising, since the procedure depends on the substitution of an initial snow density which is variable. An effect of temperature was established by Diamond and Lowry (1953, p. I-3) and the wind velocity as well as the type of the falling snow crystals are also involved. According to Equation (4) a range of density $\rho_{0}$ from $80 \mathrm{~kg} \mathrm{~m}^{-3}$ to $120 \mathrm{~kg} \mathrm{~m}^{-3}$ would cause an uncertainty of $\pm 20 \%$ in computing $\rho_{n}$ after $n$ days. The actual scatter is far better probably for the following reason: Equation (2) indicates the initial rate of settling for the density of $100 \mathrm{~kg} \mathrm{~m}^{-3}$. If the new snow has a greater density, it can be assumed that this stage, although caused by other effects, is equivalent to a certain time of deposition after which the rate of settling according to Equation (2) is already reduced. A snow density of $120 \mathrm{~kg} \mathrm{~m}^{-3}$ then corresponds to a fictitious time shift of $0.85 \mathrm{~d}$ and $80 \mathrm{~kg} \mathrm{~m}^{-3}$ to $-0.5 \mathrm{~d}$ (backwards from the starting time of Equation (2)).

If the settling and density of snow are computed for example for $t=60 \mathrm{~d}$ the following deviations result:

$$
\begin{aligned}
& H_{\mathrm{so}}=\mathrm{I} \mathrm{m} \text {, } \\
& \rho_{0} \text { substituted as } 100 \mathrm{~kg} \mathrm{~m}^{-3} \text {. } \\
& H_{\mathrm{s} 60}=291.3 \mathrm{~mm} \text {, } \\
& \rho_{60}=343.2 \mathrm{~kg} \mathrm{~m}^{-3} \text {, } \\
& \text { actual } \rho_{0}=120 \mathrm{~kg} \mathrm{~m}^{-3} \text {. } \\
& H_{\mathrm{s} 60} \rightarrow H_{\mathrm{s} 60.85}=290.1 \mathrm{~mm} \text {, } \\
& \rho_{60} \rightarrow \rho_{60.85}=344.7 \mathrm{~kg} \mathrm{~m}^{-3} \text {. } \\
& \text { actual } \rho_{0}=80 \mathrm{~kg} \mathrm{~m}^{-3} \text {, } \\
& H_{\mathrm{s} 60} \rightarrow H_{\mathrm{s}_{59.5}}=292.1 \mathrm{~mm} \text {, } \\
& \rho_{60} \rightarrow \rho_{59.5}=342.4 \mathrm{~kg} \mathrm{~m}^{-3} \text {. }
\end{aligned}
$$


Thus, when variations of the initial snow density ranging from $80 \mathrm{~kg} \mathrm{~m}^{-3}$ to $120 \mathrm{~kg} \mathrm{~m}^{-3}$ are ignored by assuming always $\rho_{0}=100 \mathrm{~kg} \mathrm{~m}^{-3}$, the resulting deviations after $60 \mathrm{~d}$ are within $\pm 0.5 \%$. Recalling that the actual snow depths are available, $H_{\mathrm{S} 60.85}$ is only used to determine $\rho_{60.85}$ (which can be also computed by Equation (4)). It is further understood that if the starting snow depth for a layer with $\rho_{0}=120 \mathrm{~kg} \mathrm{~m}^{-3}$ is $\mathrm{I} \mathrm{m}, H_{\mathrm{S}}$ for $\rho=100 \mathrm{~kg} \mathrm{~m}^{-3}$ would have been $1.2 \mathrm{~m}$. The actual snow depths are given by the settling curve starting with these values but taken up at the time $n=0, \rho_{0}=120 \mathrm{~kg} \mathrm{~m}^{-3}, H_{\mathrm{s}_{0}}=\mathrm{I} \mathrm{m}$. Consequently the actual snow depth after $60 \mathrm{~d}$ is

$$
H_{\mathrm{s} 60}(\text { actual })=1.2 H_{\mathrm{s} 60.85}=0.34^{8} \mathrm{~m},
$$

and the resulting water equivalent of the snow

$$
\begin{aligned}
H_{\mathrm{w} 60}(\text { computed }) & =\left(0.34^{8} \mathrm{~m}\right) \rho_{60} / \rho_{\mathrm{w}}=0.1194 \mathrm{~m}, \\
H_{\mathrm{w} 60}(\text { actual }) & =\left(0.34^{8} \mathrm{~m}\right) \rho_{60.85} / \rho_{\mathrm{w}}=0.12 \mathrm{~m} .
\end{aligned}
$$

The error for $\rho_{0}=80 \mathrm{~kg} \mathrm{~m}^{-3}$ is by analogy

$$
\frac{H_{\mathrm{w} 60}(\text { computed })}{H_{\mathrm{w} 60}(\text { actual })}=\frac{\rho_{60}}{\rho_{59.5}}=\frac{H_{\mathrm{s} 59.5}}{H_{\mathrm{s} 60}} .
$$

In the given example, $H_{\mathrm{w}}{ }_{60}$ is computed as

$$
{ }_{1.2} H_{\mathrm{s} 60.85} \rho_{60} / \rho_{\mathrm{w}}=H_{\mathrm{s} 60} \rho_{60} / \rho_{\mathrm{w}}+\left(\mathrm{I} .2 H_{\mathrm{s} 60.85}-H_{\mathrm{S} 60}\right) \rho_{60} / \rho_{\mathrm{w}} .
$$

In a real case, the slower decrease of snow depths can also result from subsequent snowfalls. Therefore

$$
H_{\mathrm{w} 60}=H_{\mathrm{s} 60} \rho_{60} / \rho_{\mathrm{w}}+\left(\mathrm{I} .2 H_{\mathrm{s} 60.85}-H_{\mathrm{s} 60}\right) \rho_{\tau} / \rho_{\mathrm{w}},
$$

where $\tau$ is a medium age of all new snow layers $(\tau<60 \mathrm{~d})$. The diminution of error with time is due to the characteristic shape of settling curves.

Since it takes usually several weeks or months to reach the maximum snow accumulation of a winter, the simple Equation (2) can be applied to estimate the maximum water equivalent of snow although it is not able to take into account the variable starting conditions of each snow layer.

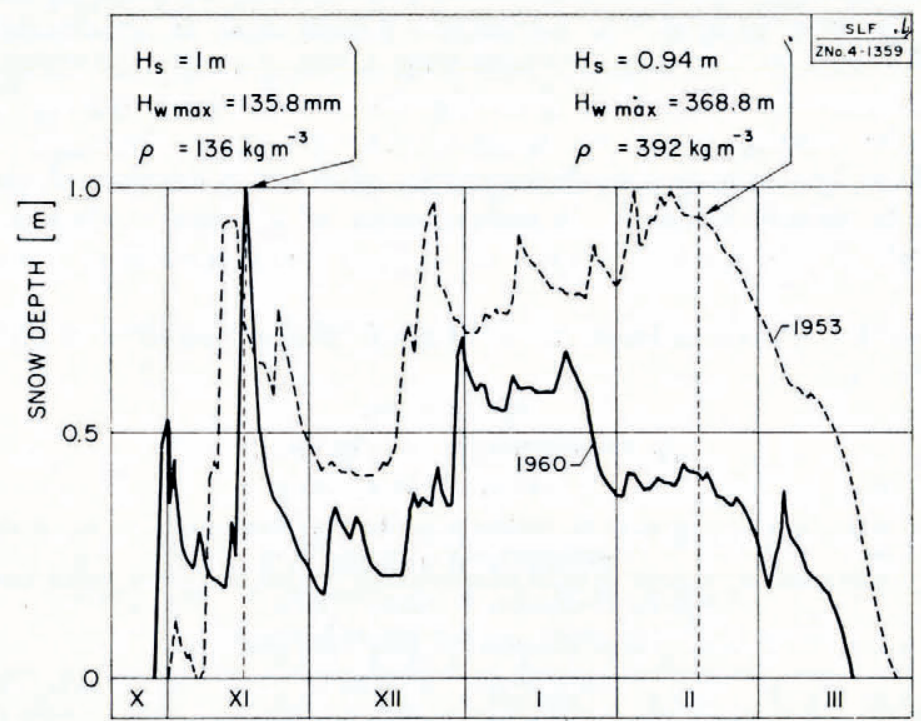

Fig. 3. Different patterns of snow accumulation, station Disentis, I $173 \mathrm{~m}$ a.s.l. 
Figure 3 shows two different patterns of snow accumulation with the computed water equivalents and densities. In converting a sequence of daily snow depths to water equivalents, the decrease of snow depth was attributed to the increase of the snow density neglecting a possible small effect of evaporation. On the other hand, an intermittent melting of snow could have affected the results especially in lower stations. Therefore, whenever the snow depth decreased more than indicated by the settling equation, it was taken as a signal of snow melt and the corresponding amount of water was subtracted.

By using the snow depth instead of the elapsed time as an index of the snow density, as for example in the formula (Schriever and Otstavnov, I968, p. 14)

$$
\rho=250+H_{\mathrm{s}}+6 \mathcal{T}
$$

where $\rho$ is in $\mathrm{kg} \mathrm{m}^{-3}, H_{\mathrm{s}}$ is in $\mathrm{cm}$ and $T$ is the average temperature in ${ }^{\circ} \mathrm{C}$ for the three coldest months of the winter, results contradictory to the age of snow are obtained:

$$
\begin{aligned}
& \rho<344 \mathrm{~kg} \mathrm{~m}^{-3} \text { for old snow in February I953, } \\
& \rho>350 \mathrm{~kg} \mathrm{~m}^{-3} \text { for new snow in November } 1959 .
\end{aligned}
$$

\section{Frequency analysis of WATER Equivalent of SNOW}

The maximum water equivalent of each winter's snow was computed for 35 stations with daily observations of the total depth of snow cover only. Together with direct measurements, 76 stations ranging from $276 \mathrm{~m}$ a.s.l. to $2540 \mathrm{~m}$ a.s.l. with a total of $\mathrm{I} 482$ years of record were available for assessing the expectancy of snow loads. The data agreed well with the Fisher-Tippett extremal distribution

$$
P(X \leqslant x)=\exp [-\exp \{-(a+x) / c\}],
$$

where $P$ is the probability that an extreme value $X$ is equal to or smaller than the variate $x$ and $a$ and $c$ are parameters.

The parameters have been evaluated (Chow, 1964) as

$$
\begin{aligned}
& a=\gamma c-\mu, \\
& c=\frac{\sqrt{ } 6}{\pi} \sigma,
\end{aligned}
$$

where $\gamma=0.57721 \ldots$ (Euler's constant), $\mu$ is the mean value and $\sigma$ is the standard deviation.

In Figure 4, the maximum water equivalents of each winter's snow measured at Weissfluhjoch are plotted against their respective return periods $T_{\mathrm{r}}$ on the Gumbel-Powell probability paper designed for the Fisher-Tippett distribution, with (Weibull, 1939, p. 29)

$$
T_{\mathbf{r}}=\frac{\mathcal{N}+\mathbf{I}}{m},
$$

where $\mathcal{N}$ is the number of items, $m$ is the order number of items arranged in descending magnitude, and

$$
y=-\ln \left[-\ln \left\{\left(T_{\mathbf{r}}-\mathbf{I}\right) / T_{\mathbf{r}}\right\}\right]
$$

where $T_{\mathrm{r}}=\mathrm{I} /(\mathrm{I}-P)$.

The relation between the average return period and the expected yearly maximum of the water equivalent of snow at Weissfluhjoch was evaluated by the least-squares method as

$$
H_{\mathrm{w}}=(2 \mathrm{I} 4.5 \mathrm{~mm})\left(-\ln \left[-\ln \left\{\left(\mathcal{T}_{\mathrm{r}}-\mathrm{I}\right) / \mathcal{T}_{\mathrm{r}}\right\}\right]\right)+72 \mathrm{I} .8 \mathrm{~mm} .
$$




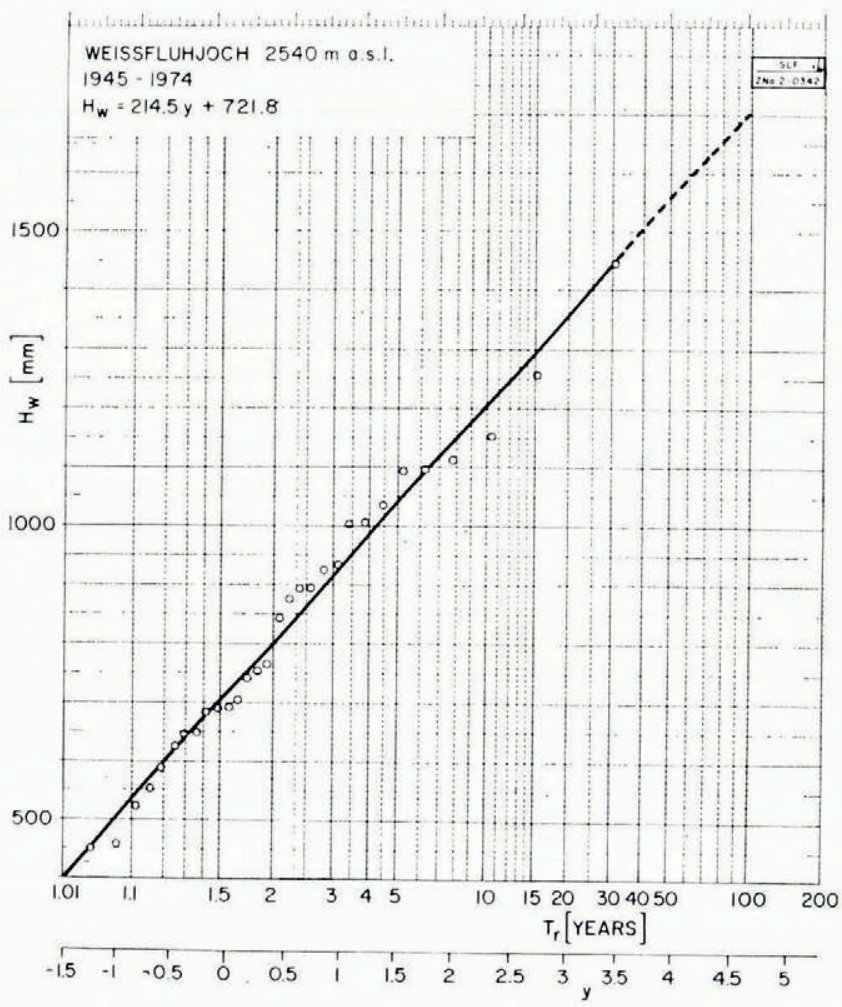

Fig. 4. Maximum yearly snow water-equivalents at Weissfluhjoch, $2540 \mathrm{~m}$ a.s.l., related to return periods.

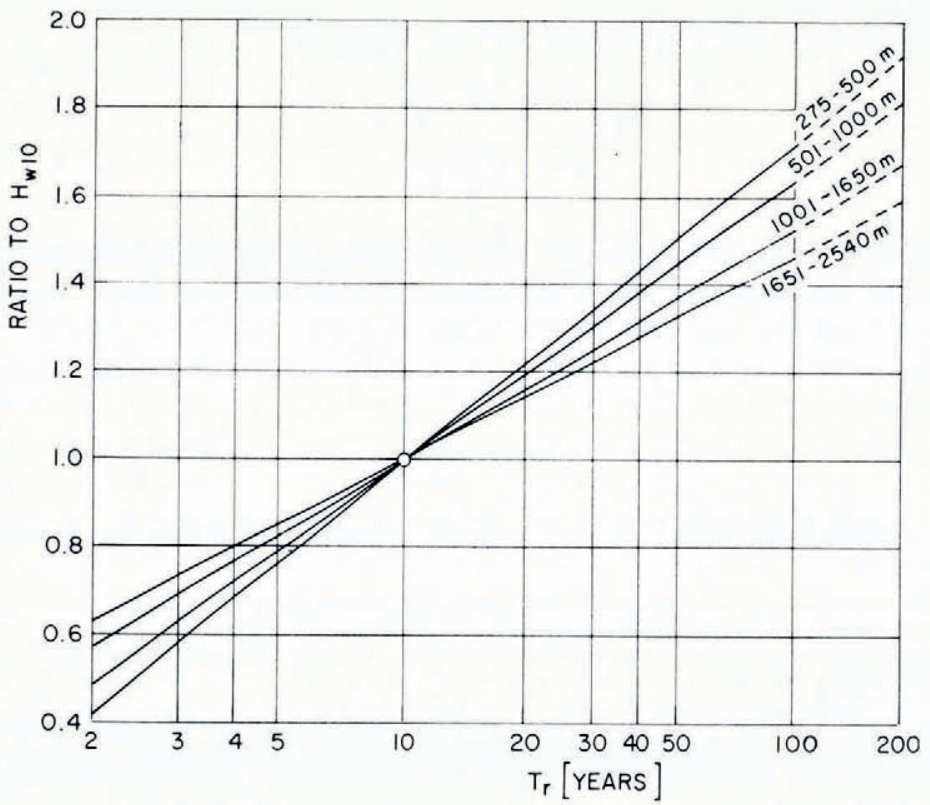

Fig. 5. Increase of the snow water-equivalent with the growing return period, average rates for the respective altitude ranges. 
Similar equations have been determined for all other stations. Exceptionally, the highest points departed upwards from the general path. This was considered as a sign of a recurrence interval greater than the length of record and such data were excluded from the fitting.

The satisfactory performance of the Fisher-Tippett distribution in this study does not prove its general validity for the frequency analysis of the water equivalent of snow. The Log-normal and the Log-Pearson Type 3 distributions, for example, have been found suitable in other cases (U.S. Weather Bureau, 1964; McAndrew, 1973).

As shown in Figure 5, the relative increase of the expected water equivalent with increasing return period generally decreases with the altitude. The frequency analysis enables the water equivalents to be determined for any desired return period within the limits of a reasonable extrapolation so that values of a comparable probability of occurrence become available for further evaluation.

\section{SNow acgumulation Related to the altitude}

In mountainous Switzerland the altitude is the dominant factor in snow accumulation. Figure 6 shows polynomial regressions

$$
H_{\mathrm{w}}=A_{0}+A_{\mathrm{r}} h+A_{2} h^{2}+\ldots+A_{m} h^{m},
$$

where $H_{\mathrm{w}}$ is the water equivalent in $\mathrm{mm}$ for $T_{\mathrm{r}}=$ Io years and $h$ is the elevation in $\mathrm{m}$ a.s.l., of which the equation

$$
H_{\mathrm{w}}=0.0003688 h^{2}-0.278 h+\mathrm{I} 53.4,
$$

was found satisfactory for practical purposes. The curves in Figure 7 have been obtained for return periods ranging from 2 years to 100 years. All available data from 76 stations have been used. Curves in Figure 8 are based on selected stations with the biggest snow accumulation in the respective elevation zones.

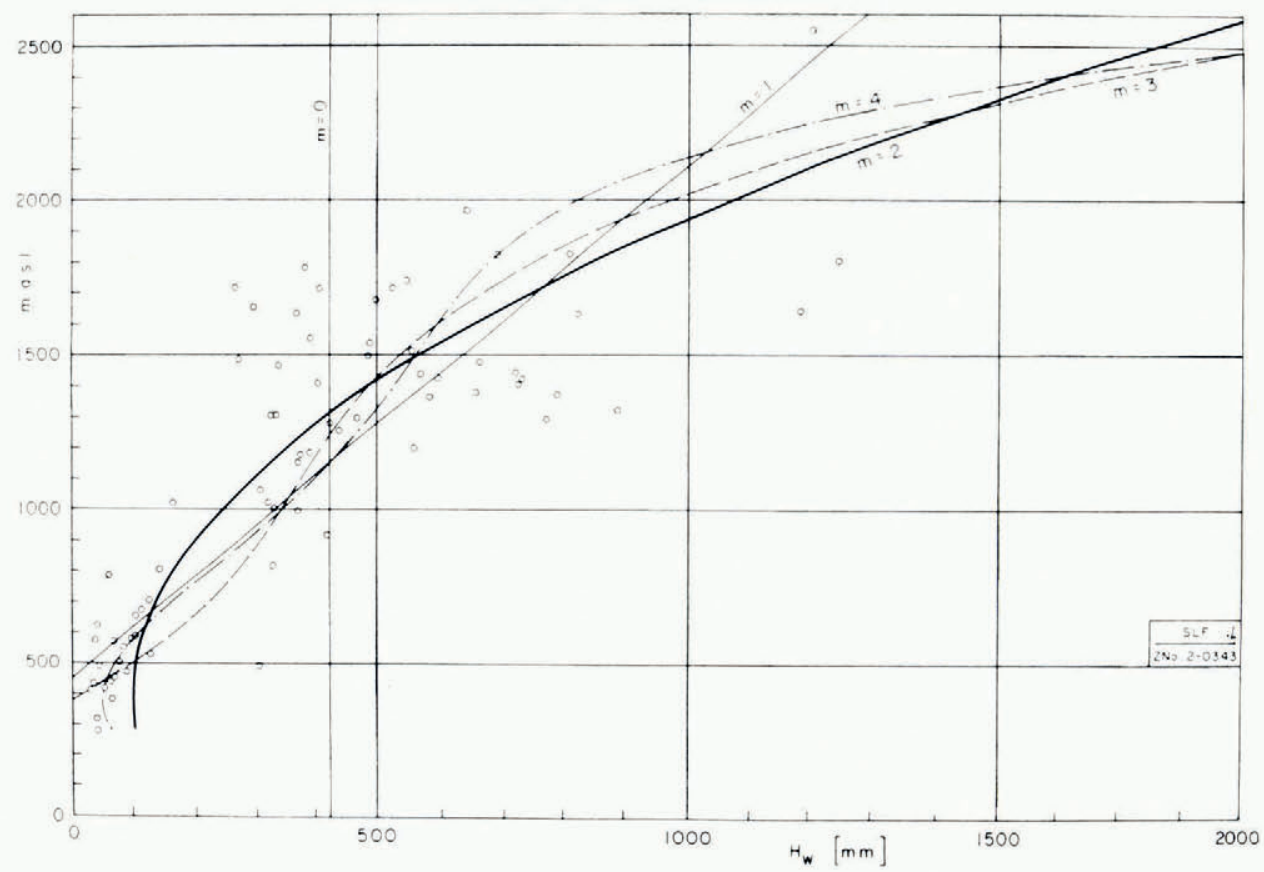

Fig. 6. Snow accumulation in Switzerland related to the altitude. 


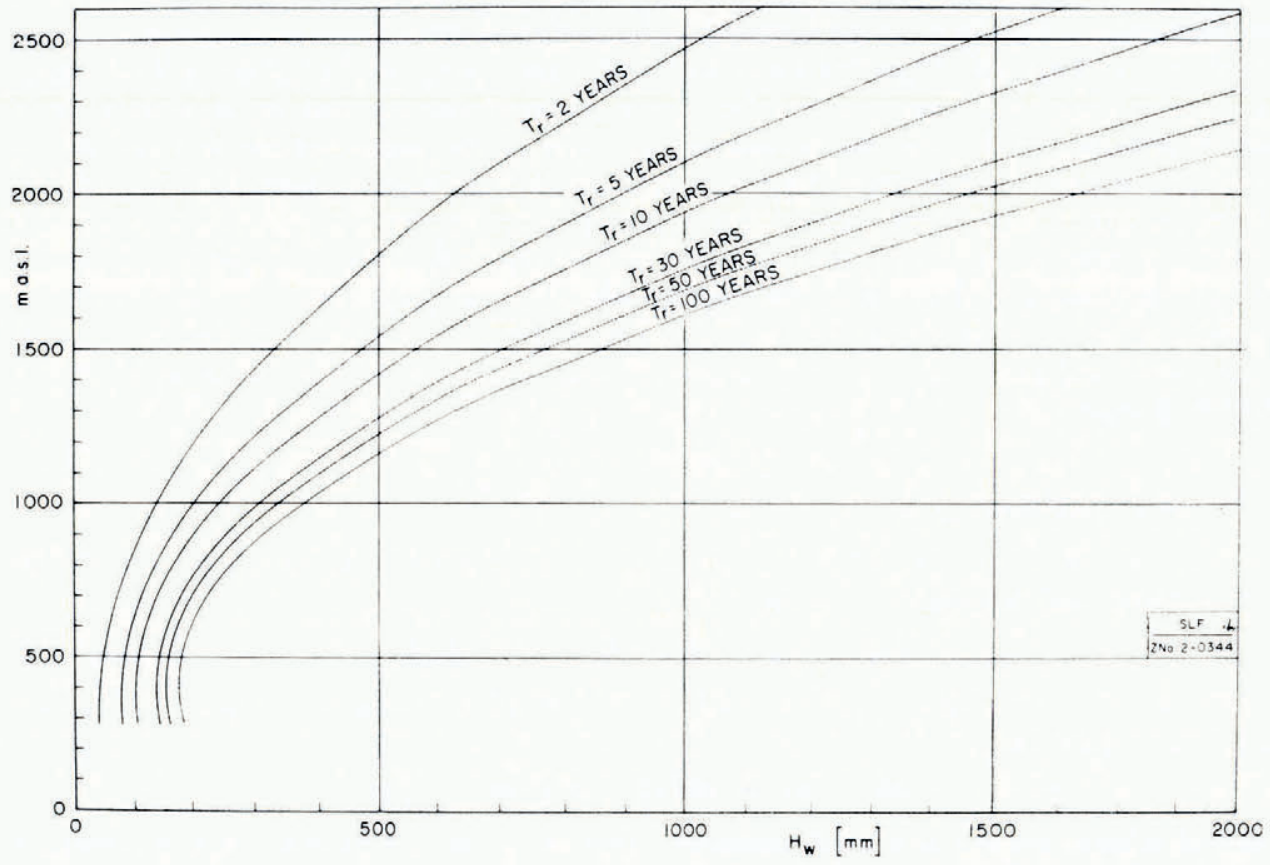

Fig. 7. Average relations between the maximum yearly snow water-equivalent and the altitude for various return periods.

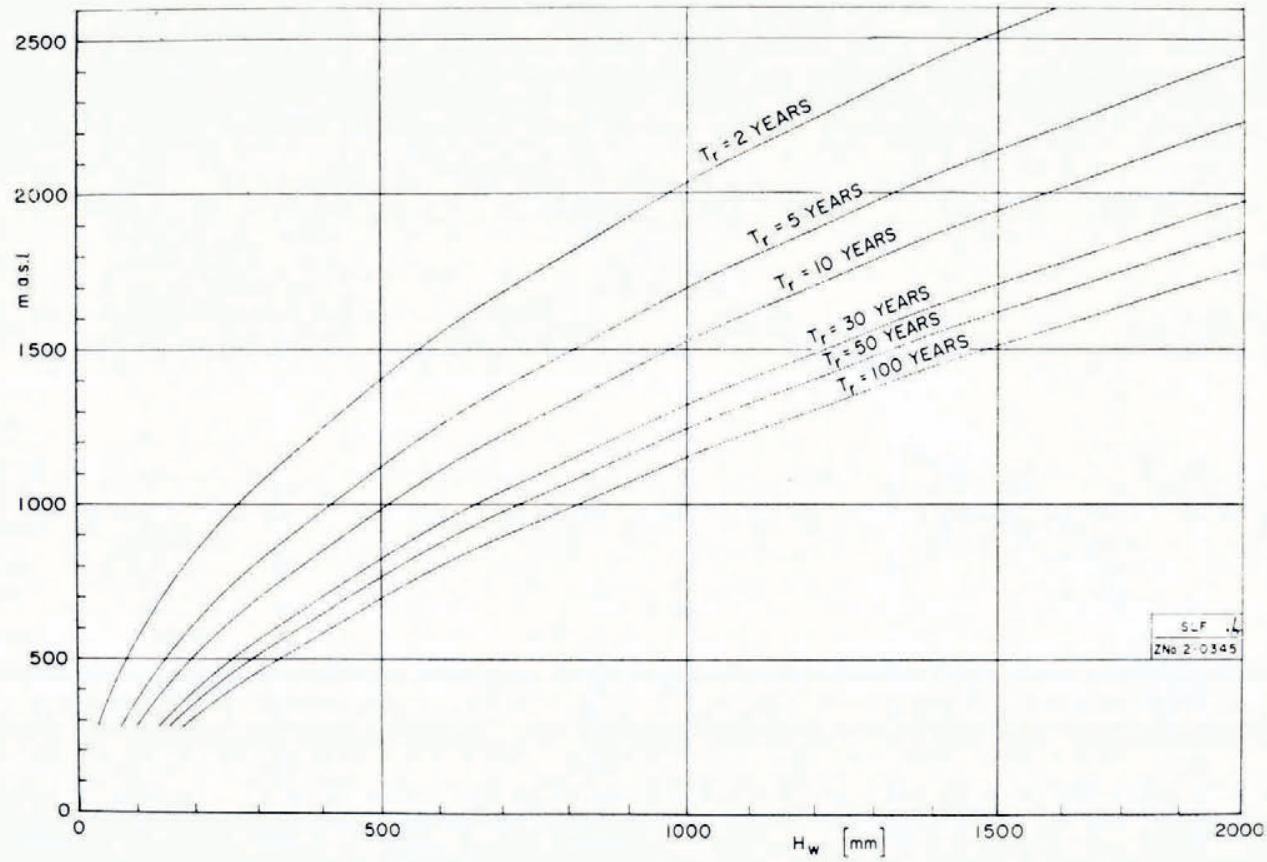

Fig. 8. Extreme curves of the maximum yearly snow water-equivalent related to the altitude for various return periods. 
With regard to the irregular distribution of rare events, the risk of a value characterized by a design return period $T_{\mathrm{r}}$ to be exceeded in a given period $\mathcal{N}$ (the desired lifetime of a structure) is obtained as

$$
\sum_{n=1}^{\mathcal{N}} p_{n}, N=\mathrm{I}-\left(\mathrm{I}-\mathrm{I} / \mathcal{T}_{\mathrm{r}}\right)^{N},
$$

where $\mathcal{N}$ is the number of years.

Probabilities for various alternatives are given in Figure 9. For $T_{\mathbf{r}}=$ io years and $\mathcal{N}=$ Io years the risk is $65 \%$. A value characterized by $T_{\mathrm{r}}=$ Ioo years is needed to reduce this risk to $10 \%$.

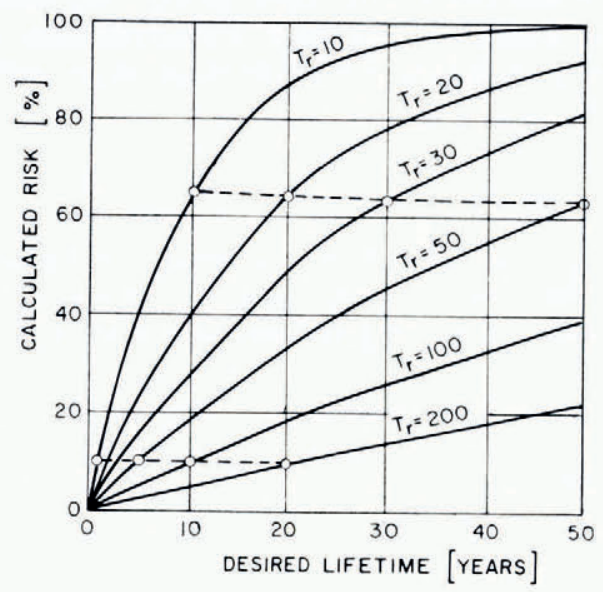

Fig. 9. Calculated-risk nomograph. ( $T_{\mathrm{r}}$ in years.)

The scatter of points in Figure 6 reflects local and regional deviations in the accumulation of snow. According to an earlier study (Zingg, 1968), the regional effect in Switzerland is less important than that of the altitude but it can become a major factor in vast areas with a changing climate influenced for example by the Great Lakes in North America (U.S. Weather Bureau, i964) or by the distance from the sea (Schaerer, I97I).

\section{Conversion OF SNOW-GOver DATA TO SNOW LOADS}

By determining snow water-equivalents to be expected on the ground, the problem of snow loads on roofs is not yet solved. Factors involved in the different accumulation of snow on roofs have been summarized (Tobiasson and Redfield, unpublished, p. 15) as follows:

$$
p_{\mathrm{r}}=c_{\mathrm{r}} c_{\mathrm{e}} c_{\mathrm{t}} p_{\mathrm{g}}
$$

where $p_{\mathrm{r}}$ is the roof snow load, $p_{\mathrm{g}}$ is the ground snow load, $c_{\mathrm{r}}$ is the regional ground-to-roof conversion factor, $c_{\mathrm{e}}$ is the exposure of the structure, and $c_{\mathrm{t}}$ is the thermal characteristic of the roof.

A variety of effects can be considered, for example (Martinec, r975)

$$
p_{\mathrm{r}}=\left(c_{\mathrm{w}} c_{\mathrm{f}} H_{\mathrm{w}}+B-M+R+A\right) g,
$$

where $p_{\mathrm{r}}$ is the roof snow load [in $\mathrm{Pa}=\mathrm{N} \mathrm{m}^{-2}$ ], $H_{\mathrm{w}}$ is the snow water-equivalent on the ground [in mm of water $=\mathrm{kg} \mathrm{m}^{-2}$ ], $c_{\mathrm{w}}$ is the effect of wind, $c_{\mathrm{P}}$ is a coefficient of the roof form, $B$ is the snow melt from the ground [in $\mathrm{mm}$ of water $=\mathrm{kg} \mathrm{m}^{-2}$ ], $M$ is the snow melt by the 
heat transfer from the building $\left[\mathrm{mm}\right.$ of water $\left.=\mathrm{kg} \mathrm{m}^{-2}\right], R$ is the incident rainwater [in $\mathrm{mm}$ of water $=\mathrm{kg} \mathrm{m}^{-2}$ ], $A$ is the load from sliding snow or avalanche [in mm of water $=\mathrm{kg} \mathrm{m}^{-2}$ ], and $g=9.8 \mathrm{I} \mathrm{m} \mathrm{s}^{-2}$.

The aerodynamic effects have been found very variable (Schriever and others, 1970). At the same time, the snow water-equivalent on the ground might have been underestimated by assuming a snow density of $19^{2} \mathrm{~kg} \mathrm{~m}^{-3}$. It is difficult to reconcile maximum snow loads on the ground in British Columbia corresponding to $600 \mathrm{~mm}$ water-equivalent (Peter and others, 1963) with ground load-altitude relations (Schaerer, I97I) or with snow surveys (Snow Survey Bulletin, 1972) whereby snow water-equivalents exceeding $2000 \mathrm{~mm}$ or even 3 ooo $\mathrm{mm}$ and snow densities around $500 \mathrm{~kg} \mathrm{~m}^{-3}$ have been measured.

The uncertainty in the ground-to-roof conversion is reflected in Building Codes valid in various countries (Schriever and Otstavnov, I968, p. I4). In most cases the altitude serves as an index of snow load. Countries like Italy understandably emphasize local climatic conditions. The form factor is accounted for by the slope of the roof resulting in considerable reductions of the snow load.

\section{Conclusion}

In order to improve data for the structural design in Switzerland, the snow waterequivalent was indirectly determined in the absence of measurements and a frequency analysis was carried out to ensure a comparability of values and a choice of design return periods.

Foreign studies demonstrated great differences between the roof load and ground load depending on specific conditions. These effects, together with regional anomalies of the snow accumulation, have to be considered as further steps leading to more realistic indications of roof loads, especially in high areas and exposed localities.

\section{REFERENGES}

Bader, H., and others. 1939. Der Schnee und seine Metamorphose, von H. Bader, R. Haefeli, E. Bucher, J. Neher, O. Eckel, C. Thams, P. Niggli. Beiträge zur Geologie der Schweiz. Geotechnische Serie. Hydrologie, Lief. 3. [English translation: U.S. Snow, Ice and Permafrost Research Establishment. Translation 14, 1954.]

Chow, V. T. 1964. Statistical and probability analysis of hydrologic data. (In Chow, V. T., ed. Handbook of applied hydrology. A compendium of water-resources technology. New York, etc., McGraw-Hill, p. 8-1-8-97.)

Diamond, M., and Lowry, W. P. 1953. Correlation of density of new snow with 700 mb temperature. U.S. Snow, Ice and Permafrost Research Establishment. Research Paper I.

McAndrew, D. W. r973. Snow load analysis and recreational uses of snow data. (In Santeford, H. S., and Smith, J. L., comp. Advanced concepts and techniques in the study of snow and ice resources. . . Washington, D.C., National Academy of Sciences, p. 1 i -2 i.)

Martinec, J. 1956. Zimní prognosy s použitím radioisotopů [Winter forecasts with the use of radioisotopes]. (In Vltavská kaskáda [The Vltava reservoir system]. Prague-Podbaba, Výzkumný Ústav Vodohospodářský, p. 45-6o.)

Martinec, J. 1975. Periodizität der Schneelasten in der Schweiz. Interner Bericht des Eidg. Institutes für Schnee- und Lawinenforschung, Nr. 545 .

Peter, B. G. W., and others. 1963. Variation of snow loads on roofs, by B. G. W. Peter, W. A. Dalgliesh and W. R. Schriever. Transactions of the Engineering Institute of Canada, Vol. 6, No. A-1, p. I-12.

Quervain, M. R. de. 1945. Die Setzung der Schneedecke. Interner Bericht des Eidg. Institutes für Schnee- und Lawinenforschung, Nr. II.

Quervain, M. R. de. 1946. Mechanisch-kristallographische Untersuchungen, 4. Zur Setzung der Schneedecke. Interner Bericht des Eidg. Institutes für Schnee- und Lawinenforschung, Nr. 26.

Schaerer, P. A. 1971. Variations of ground snow loads in British Columbia. Proceedings of the Western Snow Conference, 38 th annual meeting, p. $44-48$.

Schriever, W. R., and Otstavnov, V. A. 1968 . Snow loads. Canada. National Research Council. Division of Building Research. Research Paper No. 366, p. 1 3-33.

Schriever, W. R., and others. 1970. Snow loads, by W. R. Schriever and D. A. Lutes and B. G. W. Peter. (In Canadian structural design manual. Supplement No. 4 to the National Building Code of Canada. Ottawa, Canada. National Research Council. Associate Committee on the National Building Code, p. 567-78. (NRC No. 1 1530.$)$ ) 
Snow Survey Bulletin. 1972. [Issued by British Columbia. Dept. of Lands, Forests, and Water Resources. Water Resources Service. Water Investigation Branch.]

Tobiasson, W., and Redfield, R. Unpublished. Alaskan snow loads. [Paper presented at 24th Alaska Science Conference, 1973. Obtainable from CRREL, Hanover, N.H., U.S.A.]

U.S. Weather Bureau. 1964. Frequency of maximum water equivalent of March snow cover in north central United States. U.S. Weather Bureau. Technical Paper No. 50, p. I-24.

Weibull, W. 1939. A statistical theory of the strength of materials. Ingeniörsvelenskapsakademiens Handlingar (Stockholm), Nr. 151.

Zingg, T. 1968. Maximale Schneelasten in der Schweiz. Schweizerische Bauzeitung, 86. Jahrg., Ht. 31, p. 555-57.

\section{DISGUSSION}

L. Lliboutry: Did you find that precipitation continues to increase with altitude? We found in the Western Alps that it goes through a maximum which depends upon the altitude of the surrounding summits and then declines with further increase in altitude.

J. Martinec: The highest station included in the relation between altitude and water equivalent of snow was $2540 \mathrm{~m}$ a.s.l. For the practical use of this relation, it should be limited to $2000 \mathrm{~m}$ a.s.l. I agree that at the highest altitudes the increase in precipitation with altitude can cease or even be reversed. 